Several species of microlepidoptera which are still undetermined are very abundant on Betula alba, about Cambridge, Mass. Among them may be mentioned a case-bearer (? Coleophora), a species having a ridged cocoon (? Bucculatrix), a species the larva of which has a case made of successive rings of leaf-epidermis arranged in the form of a cornucopia, and a large leaf-miner belonging to some genus allied to Lithocolletis; the larvae of the last two species are found very late in the season, just before the leaves are destroyed by the frost.

Operophtera boreata Hübn. (Samml. europ. schmett., Spanner, I796, fig. 413-4I4). Kaltenbach (Pflanzenfeinde, 1872 , p. 599) gives Betula and Fagus as food-plants of this species. Packard (Mon. geom. moths, 1876 , p. 199) quotes Newman's description of the larva of this species.

Rheumaptera hastata Linn. (Syst. nat.,
I758, ed. 10, p. 527). Schmiedlein (Naturges. deutsch. schmett., 1805 , p. IOI-IO2) describes the larvae of this species, which he states live socially upon birch between the leaves which they spin together. Packard (Mon. geom. moths, I876, p. 165-166) quotes Newman's description of the larva, in which it is stated to feed upon Betula alba and Myrica gale. Kaltenbach (Pflanzenfeinde, 1872 , p. 4I 3 and 599) compiles authorities for the following additional food-plants of this species: Rhododendron hirsutum, Salix, and Vaccinium uliginosum. A larva of this species, taken on Betula alba, at Belmont, Mass., 4 Aug. I883, pupated I4 Aug., and appeared as imago 17 May 1884. This is one of the species of lepidoptera seen in swarms in parts of the White Mts., N. H., where specimens were taken from 8-I4 July 1874 in the greatest abundance.

( $T o$ be continued.)

\title{
SYSTEMATIC POSITION OF THE GENUS APIOCERA.
}

BY DANIEL WILLIAM COQUILLETT, ANAHEIM, CAI.

In the Berliner entom. zeitschrift for 1883, p. 287-294, Baron Osten Sacken gives his reasons for placing the genus Apiocera among the asilidae. I am strongly of the opinion, however, that its proper place is among the therevidae-an opinion which the following facts would appear to fully justify.

In the Monographs of the diptera of North America, part 1, p. 22 and p. 24, Dr. Loew defines the families asilidae and therevidae in the following words:

"Asilidae.-Three basal cells much prolonged. Third longitudinal vein of the wings furcate, the two intercalary veins always present. Third joint of the antennae simple; under lip forming a horny sheath; empodium similar to a horny bristle."

"Therevidae.--Three basal cells much prolonged; the two intercalary veins present; third longitudinal vein furcate. Antennae with a terminal style of variable form, sometimes wanting. No empodium. Under lip fleshy."

In many of the larger therevidae the empodium, or third pulvillus, is present in the form of a slender bristle. The only character of importance, therefore, whereby either of these families may be distinguished from the other is the structure of the under lip or proboscis, which 
is horny in the asilidae and fleshy in the therevidae; in other words, in the therevidae the proboscis terminates in two fleshy lips, while in the asilidae it is destitute of lips.

The genus Apiocera possesses all of the characters which Dr. Loew assigns to the asilidae except that the proboscis ends in two fleshy lips; and as this is the only character of importance wherein the therevidae differ from the asilidae, it naturally follows that this genus must be referred to the therevidae.

The characters which the Baron found to be common to Apiocera and the section asilina (l.c., p. 289-291) also exist in the larger therevidae, with the exception of the closed marginal cell; moreover, the therevidae agree with Apiocera in several of the characters wherein this genus differs from the asilina. 'Thus the majority of the therevidae have a very short antennal style, as in Apiocera; whereas, in the asilina the style is usual. ly long and bristle-like. In the therevidae, as in Apiocera, the face is very oblique, thus differing widely from the perpendicular or more or less convex face of the asilina, with its characteristic mys$\operatorname{tax}$, which is wanting in the therevidae and Apiocera. Moreover, the legs of the therevidae and Apiocer a are weaker than in the asilina, and the tarsal joints are long and slender, instead of being short and robust. So that, if Apiocera is closely related to the asilina, it is still more closely related to the therevidae.

I admit that some species of Apiocera bear a very close resemblance to several species of Erax; however, our classifica- tion is not based upon a superficial resemblance, but upon the presence or absence of certain well-marked characters. Were we justified in placing the genus Apiocera in the family asilidae it would become necessary to remove all of the therevidae to this family; but such a course is not at all desirable, as the family asilidae is already a very extensive one, and the presence or absence of lips at the tip of the proboscis is a character of very easy application.

There is not an entomologist living whose opinion on any subject relating to the diptera has greater weight than that of the Baron Osten Sacken; and I wonld not have ventured an opinion contrary to one expressed by the Baron were I not convinced beyond a doubt of the correctness of my own views. From the few words which he gives concerning the relationship of Apiocera to the therevidae it is quite evident that he had not compared them with the same care that he compared this genus with the asilina.

The genus Apiocera is represented in my collection by twenty-two specimens, which were collected in this state (California) Some of the males agree in all essential characters with Osten Sacken's description of his $A$. haruspex, but the others differ to such a degree from these, and also from each other (there being scarcely any two specimens marked exactly alike) that I am at a loss to know whether to regard them as belonging to several distinct species, or as merely varieties of one very variable species; but I incline to the latter view of the case. 

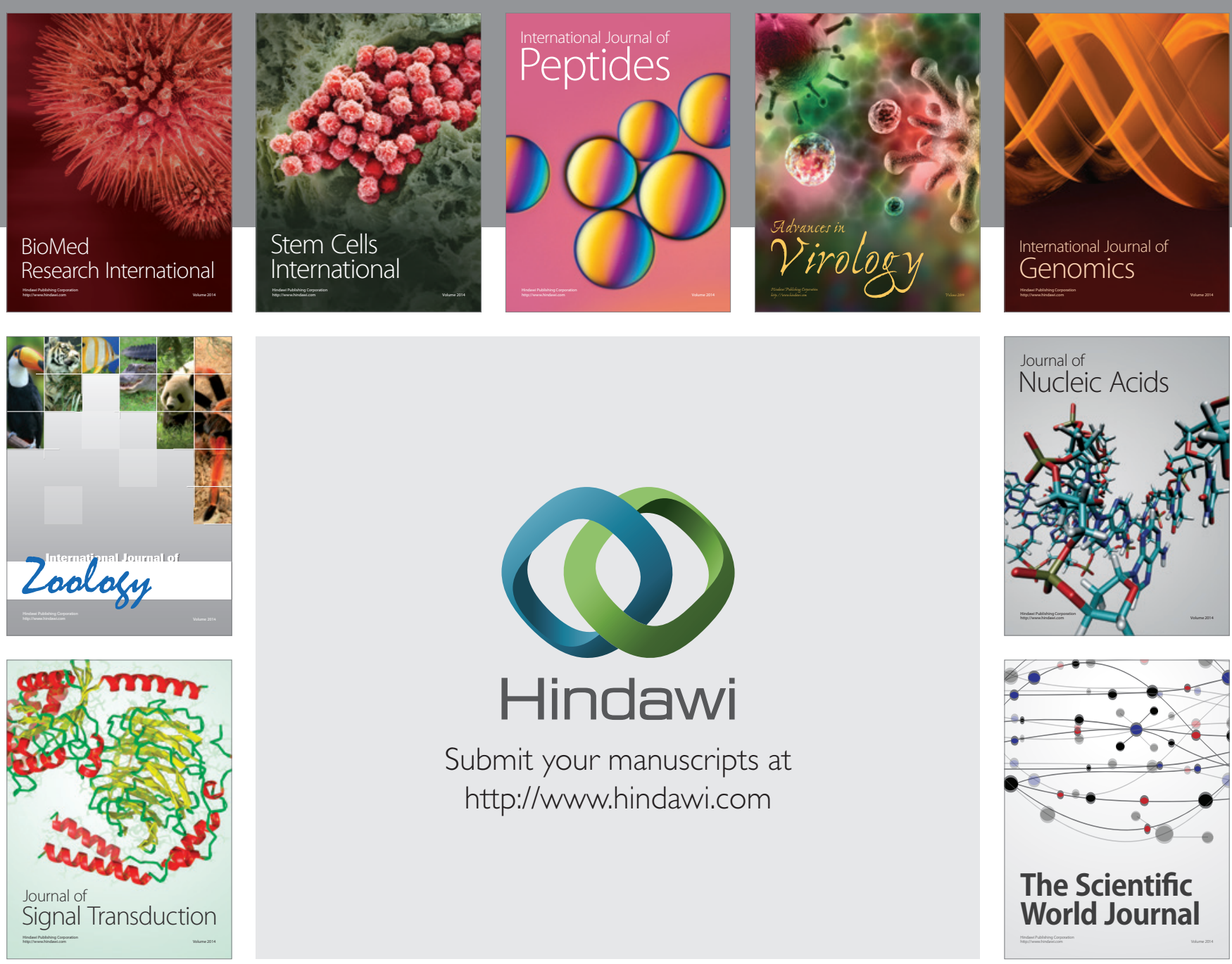

Submit your manuscripts at

http://www.hindawi.com
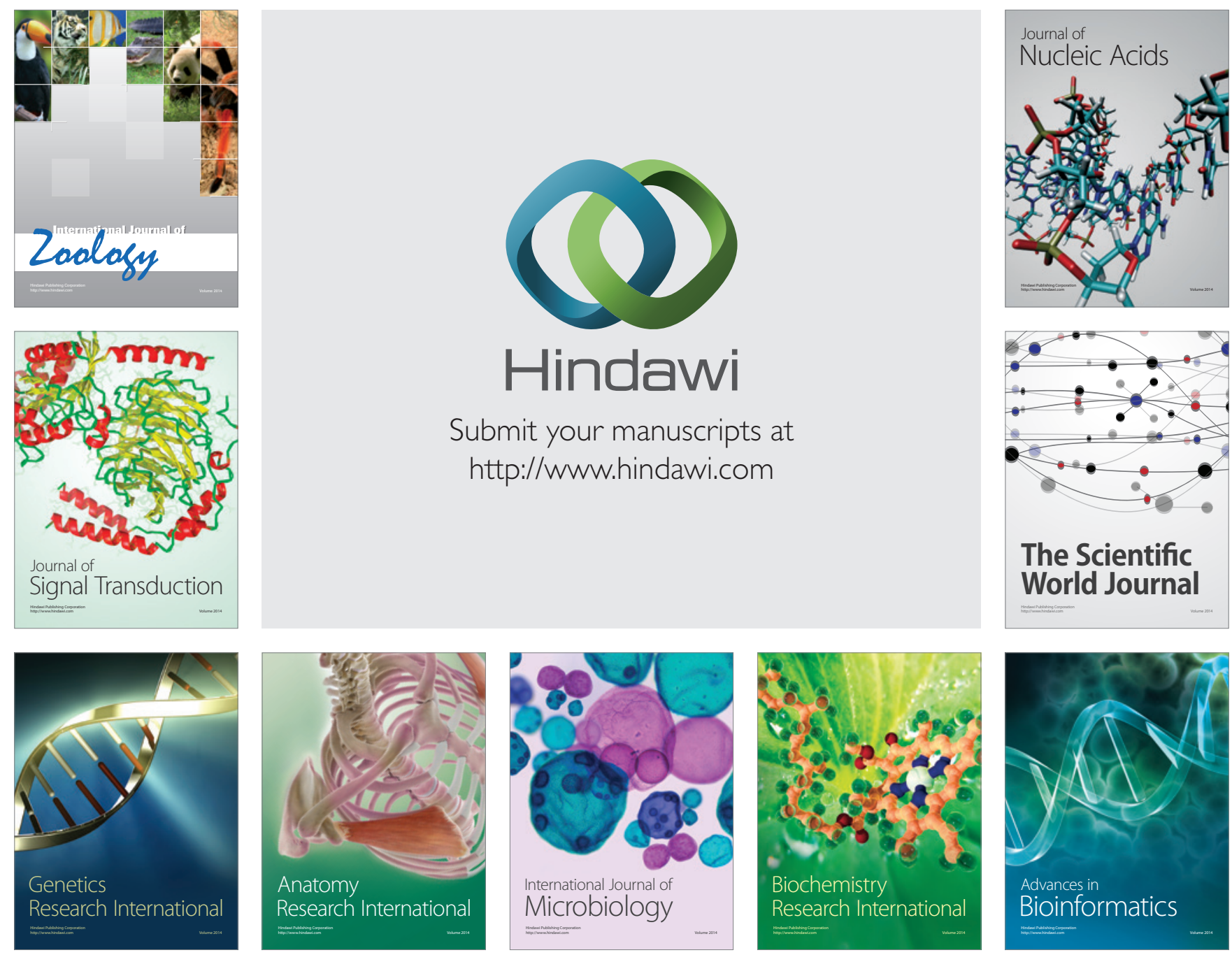

The Scientific World Journal
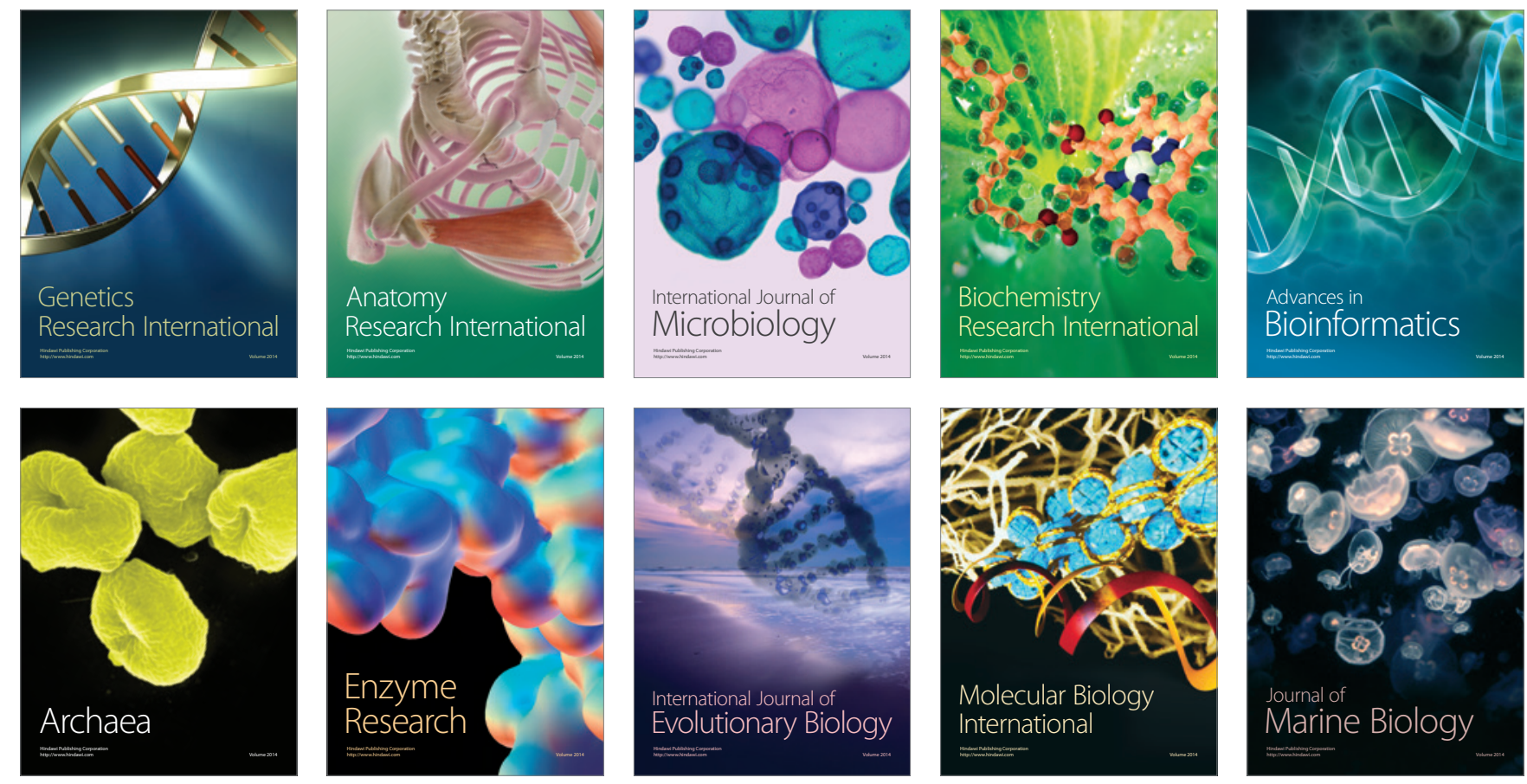